\title{
Assessment of soil quality using soil organic carbon and total nitrogen and microbial properties in tropical agroecosystems
}

\author{
Maruf K. A. Adeboye*, Abdullahi Bala, Akim O. Osunde, Anthony O. Uzoma, Ayo J. Odofin, \\ Baba A. Lawal
}

Department of Soil Science, School of Agriculture and Agricultural Technology, Federal University of Technology, Minna, Nigeria.

*Corresponding Author: enilewu@yahoo.com

Received 12 December 2010; revised 6 February 2011; accepted 15 February 2011

\begin{abstract}
Assessment of soil quality is an invaluable tool in determining the sustainability and environmental impact of agricultural ecosystems. The study was conducted to assess the quality of the soils under arable cultivation, locally irrigated and non-irrigated, forestry plantations of teak (Tectona grandis Lin.) and gmelina (Gmelina arborea Roxb.), and cashew (Anacardium occidentale Lin.) plantation agro ecosystems using soil organic carbon (SOC), soil total nitrogen (STN) and soil microbial biomass $C$ (SMBC) and $N(S M B N)$ at Minna in the southern Guinea savanna of Nigeria. Soil samples were collected from soil depths of $0-5 \mathrm{~cm}$ and $5-10 \mathrm{~cm}$ in all the agro ecosystems and analyzed for physical, chemical and biological properties. All the agro ecosystems had similar loamy soil texture at both depths. The soils have high fertility status in terms of available phosphorus and exchangeable calcium, magnesium and potassium. The irrigated arable land had significantly $(P<0.05)$ higher SOC and STN in both soil depths than all the other soils due to greater $C$ inputs into the soil and fertilizer application. The cashew plantation soil had the lowest SMBC value of $483 \mathrm{mg} \mathrm{kg}^{-1}$ while teak soil had the highest value of $766 \mathrm{mg} \mathrm{kg}^{-1}$ which was significantly $(P<0.05)$ different from that of the other soils at the surface layer. At both soil depths, in all the soils, the SMBC/SMBN ratios were $>6.6$ suggesting fungal domination in all the agroecosystems. The forestry plantation soils had higher SMBC and SMBN as a percentage of SOC and STN respectively than the cultivated arable land soils. Burning for clearing vegetation and poor stocking of forestry plantations may impair the quality of the soil. The
\end{abstract}

study suggests that the locally irrigated agroecosystem soil seems to be of better quality than the other agroecosystem soils.

Keywords: Agroecosystems; Microbial Biomass; Soil Organic Carbon; Soil Total Nitrogen; Tropical

\section{INTRODUCTION}

Soil quality is the capacity of a soil to function within ecosystem boundaries to sustain biological productivity, maintain environmental quality and promote plant and animal health and thus has a profound effect on the health and productivity of a given ecosystem and the environment related to it [1]. The soil organic carbon (SOC), soil total nitrogen (STN) and soil microbial $\mathrm{C}$ (SMBC) and $\mathrm{N}(\mathrm{SMBN})$ are some of the soil properties that are used as basic indicators in assessing soil quality [2].

The soil microbial biomass (SMB) is a small but key component of the active soil organic matter (SOM) pool and serves as a source and sink of soil nutrients [3]. It has been used to understand soil nutrient dynamics and as an ecological marker [4,5]. The SOM and STN are the major determinants and indicators of soil quality and fertility and are closely related to soil productivity in an agricultural ecosystem [6,7]. The reduction of SOC and STN will lead to adecrease in soil fertility, soil nutrient supply, porosity and an increase in soil erosion [8].

The public concern about the issue of global climate change has emphasized the need for developing and implementing strategies of agroecosystem management that will reduce carbon dioxide concentration in the atmosphere as well as improving soil fertility, SOC storage and the dynamics of $\mathrm{C}$ stock change in agroecosystems are important in evaluating the impact of agroecosystem management on global climate change [9]. Soils represent an important terrestrial stock of $\mathrm{C}$ and approximately two to three times as much as terrestrial 
vegetation and atmosphere respectively and the $\mathrm{C}$ in the SOM of agricultural land is composed of dominant terrestrial $\mathrm{C}$ stock $[10,11]$. Thus, the dynamics of SOC as affected by agroecosystem to a large extent affects the carbon dioxide concentration in the atmosphere as well as even the global climate change [12,13].

Recent interest in evaluating soil quality has been stimulated by increasing awareness that soil is a critically important component of the earth biosphere as it functions not only in the production of food and fibre but also in the maintenance of environmental quality as related to agroecosystem management and in formulating and evaluating sustainable agricultural and land use policies [14]. In Nigeria, studies have been conducted on the use of SOC, STN and SMB to evaluate effects of management practices such as legume rotation on soil fertility $[15,16]$, but there is dearth of information on the assessment of soil quality under different agroecosystems using the SOC, STN, and SMB. The present study was carried out to assess the quality of the soils under arable cultivation, locally irrigated and non-irrigated, forestry plantations of teak (Tectona grandis Lin.), and gmelina (Gmelina arborea Roxb.) and cashew (Anacardium occidentalis Lin.) plantation agroecosystems using the SOC, STN and SMB contents of the soil in the southern Guinea savanna of Nigeria.

\section{MATERIALS AND METHODS}

\subsection{Site Description}

The study site was Minna $\left(9^{\circ} 14^{\prime} \mathrm{N}, 6^{\circ} 30^{\prime} \mathrm{E}\right)$ in the southern Guinea savanna of Nigeria with a gently undulating plain topography. The climate is sub-humid tropical with mean annual rainfall of about $1200 \mathrm{~mm}(90 \%$ of the rainfall is between June and August). The mean daily temperature rarely falls below $22{ }^{\circ} \mathrm{C}$ with peaks of $40{ }^{\circ} \mathrm{C}$ and $36{ }^{\circ} \mathrm{C}$ between February to March and November to December respectively. The soils of Minna are Alfisols (USDA) developed from basement complex rocks ranging from shallow to very deep soils overlying deeply weathered gneisses and magmitites with some underlain by ironpan to varying depths [17].

\subsection{Agroecosystems}

The agroecosystem sites were the forestry plantations of teak and gmelina and cashew plantation established about six years ago by the Federal University of Technology, Minna, Nigeria and the nearby locally irrigated arable and non-irrigated arable lands. Each forestry and cashew plantations are about six hectares in size with the cashew plantation poorly stocked. The locally irrigated field nearby had over the years been continuously cultivated both in the rainy season to maize (Zea mays), yam (Dioscorea rotundata) with fertilizer application to the maize and in the dry season to vegetables including, okra (Hibiscus esculentus), garden egg (Solanum melongena) and pepper (Capsicum annum) using a nearby stream as the source of water for irrigation. The stream runs through residential and automobile mechanic areas and serves as the disposal site for domestic and automobile repair wastes. The non-irrigated arable land also near the plantations with few scattered trees of mango (Mangifera indica) had been under continuous mixed cropping with maize, okra, yam and cassava (Manihot esculentus) over the years with minimal fertilizer application during the rainy season only. In the dry season, the land is occupied dominantly by speargrass (Imperata cylindrica).

\subsection{Soil Sampling and Analysis}

Ten soil samples were collected in June, 2009, at 0-5 $\mathrm{cm}$ and $5-10 \mathrm{~cm}$ depths underneath the canopies of the trees (about $10 \mathrm{~cm}$ away from the tree base) and in the arable lands, from within the planted rows and interrow areas with a $5 \mathrm{~cm}^{2}$ soil coring tool. Each soil sample was a composite of four soil cores collected at north, south, east and west coordinates. After removing visible plant residues and pebbles, the field fresh moist soil samples were sieved with a $2 \mathrm{~mm}$ mesh sieve. Part of the sample was stored in plastic bags at $4{ }^{\circ} \mathrm{C}$ for soil microbial biomass (SMB) determinations. The remaining part was air-dried for determination of soil physical and chemical properties. All measurements were conducted within seven days of sampling. Before determination of SMB C and $\mathrm{N}$, moisture content was determined and the results are expressed on oven-dried basis.

The soil particle size distribution was determined by the Bouyoucos hydrometer method. Soil $\mathrm{pH}$ was measured in 1:2.5 soil-water suspensions with glass electrode pH meter. Organic C was determined using the WalkleyBlack wet oxidation method [18]. Total $\mathrm{N}$ was determined by the Kjeldahl digestion procedure [19]. Exchangeable bases were determined by extraction with neutral $1 \mathrm{~N}$ NH4OAc. Potassium in the extract was determined with flame photometer while calcium $(\mathrm{Ca})$ and magnesium $(\mathrm{Mg})$ were determined using the atomic absorption spectrophotometer. Available phosphorus (P) was extracted by Bray P1 method. The P concentration in the extract was determined colorimetrically using the spectronic 70 spectrophotometer. Soil microbial biomass $\mathrm{C}$ and $\mathrm{N}$ were determined by the chloroform- fumigation method [20].

\section{RESULTS AND DISCUSSION}

\subsection{Soil Texture, Reaction and Exchangeable Bases}

Selected physical and chemical properties of the soils are shown in Table 1. The soils of all the agroecosys 
Table 1. Selected physical and chemical properties of the agroecosystems.

\begin{tabular}{|c|c|c|c|c|c|c|c|c|c|c|}
\hline \multirow[t]{2}{*}{ Agroecosystems } & \multirow{2}{*}{$\begin{array}{l}\text { Depth } \\
(\mathrm{cm})\end{array}$} & \multirow{2}{*}{$\begin{array}{c}\text { Sand } \\
\left(\mathrm{g} \mathrm{kg}^{-1}\right)\end{array}$} & \multirow{2}{*}{$\begin{array}{c}\text { Silt } \\
\left(\mathrm{g} \mathrm{kg}^{-1}\right)\end{array}$} & \multirow{2}{*}{$\begin{array}{c}\text { Clay } \\
\left(\mathrm{g} \mathrm{kg}^{-1}\right)\end{array}$} & \multirow{2}{*}{ Textural class } & \multirow{2}{*}{$\begin{array}{c}\mathrm{pH} \\
\left(\mathrm{H}_{2} \mathrm{O}\right)\end{array}$} & \multirow{2}{*}{$\begin{array}{c}\text { Available P } \\
\left(\mathrm{mg} \mathrm{kg}^{-1}\right)\end{array}$} & \multicolumn{3}{|c|}{ Exchangeable bases } \\
\hline & & & & & & & & $\mathrm{Ca}$ & $\begin{array}{c}\mathrm{K} \\
(\mathrm{cmol} \mathrm{kg}\end{array}$ & $\mathrm{Mg}$ \\
\hline \multicolumn{11}{|l|}{ Arable Lands } \\
\hline \multirow[t]{2}{*}{ Irrigated } & $0-5$ & 681 & 170 & 149 & Sandy loam & 6.6 & 27 & 1.57 & 0.30 & 0.23 \\
\hline & $5-10$ & 642 & 193 & 165 & Loam & 6.6 & 26 & 1.83 & 0.36 & 0.20 \\
\hline \multirow[t]{2}{*}{ Non-irrigated } & $0-5$ & 461 & 300 & 239 & Loam & 5.0 & 21 & 2.61 & 0.15 & 0.35 \\
\hline & $5-10$ & 475 & 285 & 240 & Loam & 5.0 & 22 & 2.63 & 0.64 & 0.33 \\
\hline \multicolumn{11}{|l|}{ Plantations } \\
\hline \multirow[t]{2}{*}{ Teak } & $0-5$ & 700 & 200 & 100 & Sandy loam & 6.5 & 37 & 7.46 & 0.89 & 3.46 \\
\hline & $5-10$ & 721 & 169 & 110 & Sandy loam & 6.4 & 22 & 5.29 & 3.34 & 2.48 \\
\hline \multirow[t]{2}{*}{ Gmelina } & $0-5$ & 700 & 208 & 92 & Sandy loam & 6.2 & 20 & 4.87 & 0.48 & 2.83 \\
\hline & $5-10$ & 721 & 169 & 110 & Sandy loam & 6.9 & 33 & 2.80 & 1.96 & 2.40 \\
\hline \multirow[t]{2}{*}{ Cashew } & $0-5$ & 710 & 171 & 119 & Sandy loam & 6.3 & 33 & 7.44 & 0.49 & 2.84 \\
\hline & $5-10$ & 720 & 140 & 140 & Sandy loam & 5.8 & 24 & 7.60 & 0.34 & 1.80 \\
\hline
\end{tabular}

tems have similar loamy texture in surface soil, $0-5 \mathrm{~cm}$ and $5-10 \mathrm{~cm}$ depths. This reflects the origin of the soils from the same parent material and suggests that differences in the soils chemical and microbial properties are due to management rather than inherent differences. The soils reaction were slightly to moderately acidic at both soil depths [21]. The soil of the non-irrigated arable land had the lowest soil $\mathrm{pH}$ of 5.0 which was significantly (P $\leq 0.05$ ) lower at both soil depths than that of the other agroecosystem soils. Continuous cropping of tropical soils with or without fertilizer application results in acidification of the soil $[22,23]$.

The plantation soils had significantly $(\mathrm{P} \leq 0.05)$ higher exchangeable bases $(\mathrm{Ca}, \mathrm{Mg}, \mathrm{K})$ at both $0-5 \mathrm{~cm}$ and $5-10$ $\mathrm{cm}$ soil depths compared to the arable land soils. These results may be partly attributed to lower leaching losses of the bases due to the litter under the trees and the recycling of plant nutrients by the deep roots of the trees. The occasional burning of the under storey vegetation in the plantations can also cause liming effect of the ashes of the burned vegetation with corresponding increase in the exchangeable bases [24].

\subsection{Soil Organic Carbon and Total Nitrogen}

There was no stratification of soil organic C (SOC) and soil total N (STN) as a function of depth in all the soils except in the irrigated soil where the STN at $0-5 \mathrm{~cm}$ depth is significantly $(\mathrm{P} \leq 0.05)$ higher compared to that of the $5-10 \mathrm{~cm}$ depth (Table 4) indicating that the agroecosystem induced effect on SOC and STN extend as far as the $15 \mathrm{~cm}$ soil depth which can be considered as the surface soil. The SOC and STN values were relatively high in both depths in all the soils and had the pattern suggesting that they are intimately connected. A significant $(\mathrm{P}<0.01)$ positive relationship have been reported between SOC and STN in different tropical agroecosystems $[15,25]$. In both $0-5 \mathrm{~cm}$ and $5-10 \mathrm{~cm}$ soil depths, the irrigated arable soil had significantly $(\mathrm{P} \leq$ 0.05 ) higher amounts of SOC and STN than the other soils (Tables 3 and 4 ). The increased plant biomass produced with fertilizer application, all year round cultivation and increased nutrient input through irrigation water have probably resulted in increased returns of organic materials to the soil in the form of decaying roots, litter and crop residues [26,27], thus the highest SOC in the irrigated soil. Higher SOC have been obtained with fertilizer application in a savanna Alfisol in Nigeria [28]. Annual cropping reduces C loss from soils [29].

The arable agroecosystem soils at both soil depths had higher STN than the plantation agroecosystems with concomitant lower $\mathrm{C} / \mathrm{N}$ ratio (Tables 2 and $\mathbf{3}$ ) which is an indication of higher degree of humification and easy mineralization of organic $\mathrm{N}$ [30]. The availability of water-soluble organic $\mathrm{C}$ from rhizodeposition products which are the main energy sources for microorganisms and enhances their activity [31] may be partly responsible for the lower $\mathrm{C} / \mathrm{N}$ ratios obtained in the arable soils. The application of inorganic fertilizers which is a ready source of $\mathrm{N}$ for the microorganisms may also be responsible in the low $\mathrm{C} / \mathrm{N}$ ratio. Rhizodeposition is the release of organic materials from growing roots including exudates, lysates, mucigels, sloughed root cap cells and decaying roots [32].

\subsection{Soil Microbial Properties}

Values of the soil microbial biomass $\mathrm{C}$ (SMBC) and $\mathrm{N}$ (SMBN) in all 153 the agroecosystems were significantly $(\mathrm{P} \leq 0.05)$ higher in the surface soil than at the $5-10 \mathrm{~cm}$ depth except SMBN in the soil under gmelina (Table 4). These indicate the importance of this surface soil 
Table 2. Soil organic carbon, total nitrogen and microbial properties at 0-5 $\mathrm{cm}$ depth of the agroecosystems.

\begin{tabular}{|c|c|c|c|c|c|c|c|c|c|}
\hline Agroecosystems & $\begin{array}{r}\text { Depth } \\
(\mathrm{cm}) \\
\end{array}$ & $\begin{array}{l}\text { Org. C } \\
\left(\mathrm{g} \mathrm{kg}^{-1}\right)\end{array}$ & $\begin{array}{r}\text { Total N } \\
\left(\mathrm{g} \mathrm{kg}^{-1}\right) \\
\end{array}$ & $\mathrm{C} / \mathrm{N}$ ratio & $\begin{array}{c}\text { SMBC } \\
\left(\mathrm{mg} \mathrm{kg}^{-1}\right)\end{array}$ & $\begin{array}{c}\text { SMBN } \\
\left(\mathrm{mg} \mathrm{kg}^{-1}\right)\end{array}$ & $\mathrm{SMBC} / \mathrm{SMBN}$ & $\begin{array}{c}\text { SMBC/Org.C } \\
(\%)\end{array}$ & $\begin{array}{c}\text { SMBN/Total N } \\
(\%)\end{array}$ \\
\hline \multicolumn{10}{|l|}{ Arable Lands } \\
\hline \multirow{3}{*}{ Irrigated } & $0-5$ & $21.00 * \mathrm{a}$ & $13.78 \mathrm{a}$ & 1.5 & $693 b$ & $47.40 \mathrm{a}$ & 14.6 & 3.3 & 0.3 \\
\hline & $5-10$ & $22.40 * \mathrm{a}$ & $14.70 \mathrm{a}$ & 1.5 & $182 d$ & $27.53 b$ & 6.6 & 0.8 & 0.2 \\
\hline & $0-5$ & $13.50 \mathrm{c}$ & $7.09 \mathrm{~b}$ & 1.9 & $640 \mathrm{c}$ & $22.71 d$ & 28.2 & 4.7 & 0.3 \\
\hline Non-irrigated & $5-10$ & $14.45 b$ & $6.80 \mathrm{~b}$ & 2.1 & $240 \mathrm{c}$ & $18.59 \mathrm{e}$ & 12.9 & 1.7 & 0.3 \\
\hline \multicolumn{10}{|l|}{ Plantations } \\
\hline \multirow[t]{2}{*}{ Teak } & $0-5$ & $13.71 \mathrm{c}$ & $6.28 \mathrm{c}$ & 2.2 & $766 a$ & $29.25 c$ & 26.2 & 5.6 & 0.5 \\
\hline & $5-10$ & $12.50 \mathrm{e}$ & $5.69 \mathrm{c}$ & 2.2 & $244 \mathrm{c}$ & $23.07 \mathrm{c}$ & 10.6 & 2.0 & 0.4 \\
\hline \multirow[t]{2}{*}{ Gmelina } & $0-5$ & $15.46 \mathrm{~b}$ & $6.45 c$ & 2.4 & $690 \mathrm{~b}$ & $40.92 b$ & 16.9 & 4.5 & 0.6 \\
\hline & $5-10$ & $15.46 \mathrm{~b}$ & $6.45 c$ & 2.4 & $690 \mathrm{~b}$ & $40.92 b$ & 16.9 & 4.5 & 1.0 \\
\hline \multirow[t]{2}{*}{ Gmelina } & $0-5$ & $13.46 \mathrm{c}$ & $6.45 \mathrm{c}$ & 2.1 & $483 d$ & $41.28 b$ & 11.7 & 3.6 & 0.6 \\
\hline & $5-10$ & $13.60 \mathrm{c}$ & $5.20 \mathrm{~d}$ & 2.6 & $315 b$ & $21.14 \mathrm{~d}$ & 14.9 & 2.3 & 0.4 \\
\hline
\end{tabular}

* Means in the same column that are followed by the same letter are not significantly different at $\mathrm{P} \leq 0.05(\mathrm{n}=50)$.

Table 3. Soil organic carbon, total nitrogen and microbial properties at 5-10 $\mathrm{cm}$ depth of the agroecosystems

\begin{tabular}{|c|c|c|c|c|c|c|c|c|}
\hline Agroecosystems & $\begin{array}{l}\text { Org. C } \\
\left(\mathrm{g} \mathrm{kg}^{-1}\right)\end{array}$ & $\begin{array}{l}\text { Total N } \\
\left(\mathrm{g} \mathrm{kg}^{-1}\right)\end{array}$ & $\mathrm{C} / \mathrm{N}$ ratio & $\begin{array}{l}\text { SMBC } \\
\left(\mathrm{mg} \mathrm{kg}^{-1}\right)\end{array}$ & $\begin{array}{l}\text { SMBN } \\
\left(\mathrm{mg} \mathrm{kg}^{-1}\right)\end{array}$ & SMBC/SMBN & $\begin{array}{c}\text { SMBC/Org.C } \\
(\%)\end{array}$ & $\begin{array}{c}\text { SMBN/Total N } \\
(\%)\end{array}$ \\
\hline \multicolumn{9}{|l|}{ Arable Lands } \\
\hline Irrigated & $22.40 * \mathrm{a}$ & $14.70 \mathrm{a}$ & 1.5 & $182 d$ & $27.53 b$ & 6.6 & 0.8 & 0.2 \\
\hline Non-irrigated & $14.45 \mathrm{~b}$ & $6.80 \mathrm{~b}$ & 2.1 & $240 \mathrm{c}$ & $18.59 \mathrm{e}$ & 12.9 & 1.7 & 0.3 \\
\hline \multicolumn{9}{|l|}{ Plantations } \\
\hline Teak & $12.50 \mathrm{e}$ & $5.69 \mathrm{c}$ & 2.2 & $244 \mathrm{c}$ & $23.07 \mathrm{c}$ & 10.6 & 2.0 & 0.4 \\
\hline Gmelina & $15.46 \mathrm{~b}$ & $6.45 \mathrm{c}$ & 2.4 & $690 \mathrm{~b}$ & $40.92 b$ & 16.9 & 4.5 & 1.0 \\
\hline Cashew & $13.60 \mathrm{c}$ & $5.20 \mathrm{~d}$ & 2.6 & $315 b$ & $21.14 \mathrm{~d}$ & 14.9 & 2.3 & 0.4 \\
\hline
\end{tabular}

* Means in the same column that are followed by the same letter are not significantly different at $\mathrm{P} \leq 0.05(\mathrm{n}=50)$.

Table 4. Comparison of soil chemical and microbial properties between 0-5 cm and 5-10 $\mathrm{cm}$ depths in the agroecosystems.

\begin{tabular}{|c|c|c|c|c|c|}
\hline Agroecosystems & $\begin{array}{c}\text { Depth } \\
(\mathrm{cm})\end{array}$ & $\begin{array}{c}\text { Org. C } \\
\left(\mathrm{g} \mathrm{kg}^{-1}\right)\end{array}$ & $\begin{array}{l}\text { Total N } \\
\left(\mathrm{g} \mathrm{kg}^{-1}\right)\end{array}$ & $\begin{array}{c}\text { SMBC } \\
\left(\mathrm{mg} \mathrm{kg}^{-1}\right)\end{array}$ & $\begin{array}{c}\text { SMBN } \\
\left(\mathrm{mg} \mathrm{kg}^{-1}\right)\end{array}$ \\
\hline \multicolumn{6}{|l|}{ Arable Lands } \\
\hline \multirow[t]{2}{*}{ Irrigated } & $0-5$ & $21.00 \mathrm{a}^{*}$ & $13.78 \mathrm{a}$ & $693 a$ & $47.40 \mathrm{a}$ \\
\hline & $5-10$ & $22.40 \mathrm{a}$ & $6.80 \mathrm{~b}$ & $240 \mathrm{~b}$ & $27.53 b$ \\
\hline \multirow[t]{2}{*}{ Non-irrigated } & $0-5$ & $13.50 \mathrm{a}$ & $7.09 a$ & $640 \mathrm{a}$ & $22.71 \mathrm{a}$ \\
\hline & $5-10$ & $14.45 \mathrm{a}$ & $6.80 \mathrm{a}$ & $240 \mathrm{~b}$ & $18.59 \mathrm{~b}$ \\
\hline \multicolumn{6}{|l|}{ Plantations } \\
\hline \multirow[t]{2}{*}{ Teak } & $0-5$ & $13.71 \mathrm{a}$ & $6.28 \mathrm{a}$ & 766 & $29.25 \mathrm{a}$ \\
\hline & $5-10$ & $12.50 \mathrm{a}$ & $5.69 \mathrm{a}$ & $244 b$ & $23.07 \mathrm{a}$ \\
\hline \multirow[t]{2}{*}{ Gmelina } & $0-5$ & $15.40 \mathrm{a}$ & $6.45 \mathrm{a}$ & $690 \mathrm{a}$ & $40.92 b$ \\
\hline & $5-10$ & $12.60 \mathrm{a}$ & $4.71 \mathrm{a}$ & $580 \mathrm{~b}$ & $44.78 \mathrm{a}$ \\
\hline \multirow[t]{2}{*}{ Cashew } & $0-5$ & $13.46 \mathrm{a}$ & $6.45 \mathrm{a}$ & $483 a$ & $41.28 \mathrm{a}$ \\
\hline & $5-10$ & $13.60 \mathrm{a}$ & $5.20 \mathrm{a}$ & $315 b$ & $21.14 \mathrm{~b}$ \\
\hline
\end{tabular}

* Means followed by the same letter in the same column of each agroecosystem are not significantly different at $\mathrm{P} \leq 0.05(\mathrm{n}=50)$

layer, $0-5 \mathrm{~cm}$ depth, for microbial meditated processes such as nutrient cycling and decomposition. Loss of this surface soil through human or natural disturbances would be detrimental to the functioning of these ecosystems [33]. The SMBC values ranged from 483-766 mg $\mathrm{kg}^{-1}$ at the $0-5 \mathrm{~cm}$ and $182-580 \mathrm{mg} \mathrm{kg}^{-1}$ at $5-10 \mathrm{~cm}$ soil depths (Tables 2 and 3). These values are in the middle of values of 115-1231 mg kg-1 reported by [34] and [35] and $61-1620 \mathrm{mg} \mathrm{kg}^{-1}$ by [36] in other terrestrial ecosystems. The values are lower than the values of 1000- 
$2000 \mathrm{mg} \mathrm{kg}^{-1}$ recorded in humid tropical forest in Amazonia $[37,38]$. The soil under the cashew plantation had the lowest value of SMBC, $483 \mathrm{mg} \mathrm{kg}^{-1}$, at the $0-5 \mathrm{~cm}$ soil depth. The poor stocking of the plantation and the clearing of the undergrowth by burning which resulted in relatively low SOC, $13.60 \mathrm{~g} \mathrm{~kg}^{-1}$ may be the reason for this result. This finding support that of [29] and [39] that SOC loss increases and microbial biomass declines when residues are removed by burning. The size of the microbial biomass is mainly potentially related to $\mathrm{C}$ inputs [3].

The SMBN values obtained in this present study, 22.71-47.40 mg kg${ }^{-1}$ at $0-5 \mathrm{~cm}$ and $18.59-44.78 \mathrm{mg} \mathrm{kg}^{-1}$ at $5-10 \mathrm{~cm}$ soil depths (Tables 2 and 3 ) are comparable with the ranges, $25.6--42.2 \mathrm{mg} \mathrm{kg}^{-1}$ reported by [40] and $20-46 \mathrm{mg} \mathrm{kg}^{-1}$ by [41]. At the $0-5 \mathrm{~cm}$ soil depth, the irrigated arable agroecosystem which had the highest SOC and STN also had the highest SMBN value of $47.40 \mathrm{mg}$ $\mathrm{kg}^{-1}$ which was significantly $(\mathrm{P} \leq 0.05)$ higher compared to the other agroecosystems. The relatively higher amounts of residues produced due to cultivation in both the rainy and dry seasons and inorganic fertilization may be responsible for the high SMBN values. The application of inorganic fertilizer and increased $\mathrm{C}$ inputs into the soil result in increased SMBN $[42,43]$.

The SMBC/SMBN ratio has often been used to describe the structure of the microbial community [44]. A low SMBC/SMBN ratio indicates that the microbial biomass contains a higher proportion of bacteria whereas a high value suggests that fungi predominate in the microbial population [45]. The SMBC/SMBN ratios obtained in this study were relatively high, $>11.7$ in the $0-5$ $\mathrm{cm}$ depth and $>6.6$ in the $5-10 \mathrm{~cm}$ depths (Tables 3 and 4) indicating the predominance of fungi in these soils. Reference [46] reported SMBC/SMBN ratios varying from 5.2 in an arable soil to 20.8 in a forest soil. The surface soil had relatively higher ratios than the lower depth in all the agroecosystem soils. The decline in SMBC/ SMBN ratio from the $0-5 \mathrm{~cm}$ to $5-10 \mathrm{~cm}$ soil depth may be an indication of a shift from fungal to bacteria population at the lower depth [47].

The SMBC and SMBN when expressed as percentages of SOC and STN respectively give an estimation of the quantities of nutrients in the microbial biomass, organic matter dynamics and substrate availability in soils [48,44]. From available studies, [3] estimated that SMBC accounted for $2 \%-5 \%$ of SOC and SMBN for $1 \%-5 \%$ of STN. In both $0-5 \mathrm{~cm}$ and $5-10 \mathrm{~cm}$ soil depths, the SMBC accounted for between $0.8 \%-5.6 \%$ of SOC while SMBN was $0.2 \%-1.0 \%$ of STN (Tables 2 and 3). The range of SMBC as a percentage of SOC obtained in this study is comparable to the range of $0.99 \%-4.30 \%$ reported for some New Zealand soils by [48]. The SMBN as a per- centage of STN obtained are lower than the ranges reported in literature by other workers for arable, pasture and forest agroecosystems $[40,44,46]$. These low values indicate that the microbial biomass is not important as a sink for $\mathrm{N}$ in these agroecosystems [46]. The SMBC as a percentage of SOC were higher in the surface soil, 0-5 $\mathrm{cm}$ than $5-10 \mathrm{~cm}$ soil depth in all the soils. These results may be due to greater $\mathrm{C}$ and $\mathrm{N}$ inputs, which are of a quality stimulating greater soil microbial biomass production, into the surface soil [48].

\subsection{Correlation of Soil Organic Carbon and Total Nitrogen and Microbial Properties}

Correlation analysis of SOC, STN and SMB measurements at both $0-5 \mathrm{~cm}$ and $5-19 \mathrm{~cm}$ soil depths revealed significant and non-significant correlations between the variables assayed (Tables 5 and $\mathbf{6}$ ). At the 0-5 $\mathrm{cm}$ soil depth, SOC was strongly related $(\mathrm{P} \leq 0.0001)$ to STN $(r=0.96)$ and SMBN $(r=0.68)$ while STN was strongly related to SMBN $(r=0.56, \mathrm{P} \leq 0.0001)$. These results indicate that SMBN levels in the soils were determined by SOC and STN at the surface soil. Numerous other studies in terrestrial ecosystems have found strong correlations between SMBN and STN $[33,44,49,50]$. Reference [33] has reported close relationship between SMBN and SOC in shrub-steppe agroecosystem in North America. SMBN was highly related $(r=0.84, \mathrm{P} \leq$ $0.0001)$ to SMBC at the $5-10 \mathrm{~cm}$ soil depth. These results suggest that both SMBC and SMBN are influenced by the same factors at this soil depth. Highly significant correlations have been reported for different terrestrial agroecosystems by other workers $[16,44,46,51]$. The SMBC had a highly significant $(\mathrm{P} \leq 0.0001)$ negative

Table 5. Matrix of correlation coefficients for soil chemical and microbial properties at $0-5 \mathrm{~cm}$ depth of the agroecosystems.

\begin{tabular}{lllll}
\hline Variables & Org. C & Total N & SMBC & SMBN \\
\hline Org. C. & - & & & \\
Total N & $0.96^{* * *}$ & - & & \\
SMBC & $0.27 \mathrm{NS}$ & $0.18 \mathrm{NS}$ & & \\
SMBN & $0.68^{* * *}$ & $0.56^{* * *}$ & $-0.20 \mathrm{NS}$ & \\
\hline
\end{tabular}

***Significant at $\mathrm{P} \leq 0.0001$, NS-Not significant

Table 6. Matrix of correlation coefficients for soil chemical and microbial properties at $5-10 \mathrm{~cm}$ depth of the agroecosystems.

\begin{tabular}{lllll}
\hline Variables & Org. C & Total N & SMBC & SMBN \\
\hline Org. C. & - & & & \\
Total N & $0.99 * * *$ & - & & \\
SMBC & $-0.53 * * *$ & $-0.58 * * *$ & & \\
SMBN & $-0.09 \mathrm{NS}$ & $-0.11 \mathrm{NS}$ & $0.84 * * *$ & \\
\hline
\end{tabular}

*** Significant at $\mathrm{P} \leq 0.0001, \mathrm{NS}-$ Not significant 
relationship with SOC $(r=-0.53)$ and STN $(r=-0.58)$ at the $5-10 \mathrm{~cm}$ soil depth. The microorganisms at this lower depth are possibly subjected to stress factor of oxygen availability. Another possible stress factor that the microorganisms can be subjected to at this depth could be substrate availability as a result of the higher proportion of the soil organic matter being in the form of humified $\mathrm{C}$ and inactive $\mathrm{N}$ that are not substrate for microorganisms. Imposition of stress factors on the microbial biomass will increase its maintenance energy requirement which may reduce the yield efficiency of the biomass and increase the death rate of the biomass [51, 52].

\section{CONCLUSIONS}

Arable crop cultivation in both rainy and dry seasons with fertilizer application was a good measure in improving the quality of the soil especially in terms of SOC and STN. The surface soil, $0-5 \mathrm{~cm}$, was the main site for microbial meditated processes of nutrient cycling and decomposition in all the agroecosystems. The clearing of the forest undergrowth by burning and poor stocking of plantations may impair the quality of the soil. There was no discernable effect of the agroecosystems on the soil microbial biomass. The microorganisms were more active in the plantation soils due to their having more $\mathrm{C}$ and $\mathrm{N}$ immobilized in their microbial biomass. Generally, from this study, the SOC, STN, biomass C and N in SOC and STN respectively all seem to be suitable diagnostic indicator of the quality of the soil of these agroecosystems.

\section{REFERENCES}

[1] Doran, J.W., Sarrantonio, M. and Janke, R. (1994) Strategies to promote soil quality and health. Proceedings of the OECD Co-operative Research project on Biological Resource Management, 1, 230-237.

[2] Doran, J.W. and Parkin, T.B. (1994) Defining and assessing soil quality. Special Publication of the Soil Science Society of America, 35, 3-21.

[3] Smith, J.L. and Paul, E.A. (1990) The significance of soil microbial biomass estimation. Publication of Soil Biology and Soil Biochemistry, 6, 357-396.

[4] Paul, E.A. and Voroney, R.P. (1980) Nutrient and energy flows through soil microbial biomass. Contemporary Microbial Ecology, 1, 215-237.

[5] Parton, W.J., Sandford, R.L., Sanchez, P.A. and Stewart, K.W.B. (1989) Modelling soil organic matter dynamics in tropical soils. Publication of the University of Hawaii, 240, 153-171.

[6] Reeves, D.W. (1997) The role of soil organic manure in maintaining soil quality in continuous cropping systems. Soil Tillage Research, 43, 131-167. doi:10.1016/S0167-1987(97)00038-X

[7] Al-Kaisi, M.M., Yin, X.H. and Licht, M.A. (2005) Soil carbon and nitrogen changes as influenced by tillage and cropping systems in some Iowa soils. Agriculture, Ecosystem and Environment, 105, 635-647.

[8] Gray, L.C. and Morant, P. (2003) Reconciling indigenous knowledge with scientific assessment of soil fertility changes in southwestern Burkina Faso. Geoderma, 111, 425-437. doi:10.1016/S0016-7061(02)00275-6

[9] Smith, P., Martimo, D., Cal, Z., Gwary, D., Janzen, H.H., Kumar, P., McCarl, B., Ogle, S., O’Maria, F., Rice, C., Scholes, R.J., Sirotenko, O., Howden, M., McAllister, T., Pan, G., Romanenkov, V., Schneider, U., Towprayoon, S., Wattenbach, M. and Smith, J.U. (2008) Greenhouse gas mitigation in agriculture. Philosophical Transactions of the Royal Society B, 363, 789-813.

[10] Davdson, E.A., Trumbore, S. and Amundson, R. (2000) Biogeochemistry; soil warming and organic carbon content. Nature, 408, 789-790. doi:10.1038/35048672

[11] Janzen, H.H., Campbell, C.A. and Ellert, B.H. (1997) Sol organic matter dynamics and relationship to soil quality. Publication of Elsevier Scientific Company, 25, 277-292.

[12] Tan, Z.X. and Lal, R. (2005) Carbon sequestration potential estimates with changes in land use and tillage practice in Ohio, USA. Agriculture, Ecosystem and Environment, 111, 140-152.

[13] Huang, B., Sun, W., Zhao, Y., Zhu, J., Yang, R., Zou, Z., Ding, F. and Su, J. (2007) Temporal and spatial variability of soil organic matter and total nitrogen in an agricultural ecosystem as affected by farming practices. Geoderma, 139, 336-345.

[14] Granatstein, D. and Bezdicek, D.F. (1992). The need for a soil quality index: Local and regional perspectives. American Journal of Alternative Agriculture, 17, 12-16.

[15] Adeboye, M.K.A., Iwuafor, E.N.O. and Agbenin, J.O. (2006) The effects of crop rotation and nitrogen fertilization on soil chemical and microbial properties in a Guinea savanna Alfisol of Nigeria. Plant and Soil, 281, 97-107. doi:10.1007/s11104-005-3828-5

[16] Yusuf, A.A., Abaidoo, R.C., Iwuafor, E.N.O., Olufajo, O.O. and Sanginga, N. (2009) Rotation effects of grain legumes and fallow on maize yield, microbial biomass and chemical properties of an Alfisol in the Nigerian savanna. Agriculture, Ecosystem and Environment, 129, 325-331.

[17] FDALR (1990) Literature review of soil fertility investigation in Nigeria. Publication of the Federal Department of Agriculture and Land Resources, Lagos, Nigeria, 2, 116-158.

[18] Nelson, D.W. and Sommers, L.E. (1982) Total carbon, organic carbon and organic matter. Publication of the American Society of Agronomy, 9, 539-579.

[19] Bremner, J.S. and Mulvaney, C.S. (1982) Nitrogen-total. Publication of the American Society of Agronomy, 9, 580 623.

[20] Anderson, J.M. and Ingram, J.S.I. (1993) Tropical Soil Biology and Fertility: A Handbook of Methods. Publication of CABI, Wallingford, UK, 2, 68-70.

[21] Brady, N.C. and Weil, R.R. (1999) The nature and properties 279 of soils. Publication of Prentice Hall Inc., New Jersey, USA, 12, 343-376.

[22] Kang, B.T. (1993) Changes in soil chemical properties and crop performance with continuous cropping on an Entisol in the humid tropics. Publication of IITA/K.U., Leuven, 1, 297-305. 
[23] Kang, B.T. and Balasubramanian, V. (1990) Long term fertilizer trials on Alfisols in West Africa. Transactions of XIV International Soil Science Society Congress, Kyoto, Japan, 4, 25-68.

[24] Nounamo, L., Yemefack, M., Tchienkoua, M. and Njomgang, R. (2002) Impacts of natural fallow duration on topsoils characteristics of a Ferralsol in sduthern Cameroon. Nigerian Journal of Soil Research, 3, 52-57.

[25] Haron, K., Brookes, P.C., Anderson, J.M. and Zakaria, Z.Z. (1998) Microbial biomass and soil organic matter dynamics in oil palm (Elaeis guineensis Jacq.) plantations in West Malaysia. Soil Biology and Biochemistry, 30, 547-552. doi:10.1016/S0038-0717(97)00217-4

[26] Haynes, R.J. and Naidu, R. (1998) Influence of lime, fertilizer and manure application on soil organic matter content and soil physical conditions: A review. Nutrient Cycling in Agroecosystem, 51, 123-137.

[27] Bi, L., Zhang, B., Liu, G., Li, Z., Liu, Y., Ye, C., Yu, X., Lai, T., Zhang, J., Yin, J. and Liang, Y. (2009) Long term effects of organic amendments on the rice yields for double rice cropping systems in subtropical China. Agriculture, Ecosystem and Environment, 129, 534-541. doi:10.1016/i.agee.2008.11.007

[28] Ogunwole, J.O. (2005). Changes in an Alfisol under long-term application of manure and inorganic fertilizer. Soil Use and Management, 21, 260-261.

[29] Collins, H.P., Rasmussen, P.E. and Douglas, Jr., C.L. (1992) Crop 300 rotation and residue management effects on soil carbon and microbial dynamics. Soil Science Society of America Journal, 56, 783-788.

[30] Bai, J.H., Ouyang, H., Deng, W., Zhu, Y.M., Zhang, X.L. and Wang, Q.G. (2005) Spatial distribution characteristics of organic matter and total nitrogen of marsh soils in river marginal wetlands. Geoderma, 124, 181-192.

[31] Theng, B.K.G., Tate, K.R. and Sollins, P. (1989) Constituents of organic matter in temperate and tropical soils. Publication of the University of Hawaii, 3, 5-32.

[32] Whipps, J.M. (1990) Carbon economy. Publication of John Wiley and Sons, New York, 1, 59-97.

[33] Bolton, Jr., H., Smith, J.L. and Link, S.O. (1993) Soil microbial biomass and activity of a disturbed and undisturbed shrub-steppe ecosystem. Soil Biology and Biochemistry, 25, 545-552. doi:10.1016/0038-0717(93)90192-E

[34] Anderson, T.-H. and Domsch, K.H. (1989) Ratio of microbial biomass carbon to total organic carbon in arable soils. Australian Journal of Soil Research, 30, 195-207.

[35] Insam, H., Parkinson, D. and Domsch, K.H. (1989) Influence of macroclimate in soil microbial biomass. Soil Biology and Biochemistry, 21, 211-221.

[36] Srivastava, S.C. and Singh, J.S. (1988) Carbon and phosphorus in the soil biomass of some tropical soils of India. Soil Biology and Biochemistry, 20, 743-747.

[37] Luizao, R.C.C., Bonde, T.A. and Rosswall, T. (1992) Seasonal variation of soil microbial biomass-The effects of clear felling a tropical rainforest and establishment of pasture in the Central Amazon. Soil Biology and Biochemistry, 24, 805-813. doi:10.1016/0038-0717(92)90256-W

[38] Henrot, J. and Robertson, J.P. (1994) Vegetation removal in two soils of the humid tropics-Effect on microbial biomass. Soil Biology and Biochemistry, 26, 111-116.

[39] Biederbeck, V.O., Campbell, C.A., Bowren, K.E., Schnitzer, M. and McIver, R.N. (1980) Effect of burning cereal straw on soil properties and grain yields in Saskatchewan. Soil Society of America Journal, 44, 103-111.

[40] Singh, H. and Singh, K.P. (1993) Effect of residue placement and chemical fertilizer on soil microbial biomass under tropical dryland cultivation. Boilogy and Fertility of Soils, 16, 275-281.

[41] Srivastava, S.C. and Singh, J.S. (1989). Effect of cultivation on microbial carbon and nitrogen in the tropical forest soil. Bioogy and Fertility of Soils, 8, 343-348.

[42] Ocio, J.A., Brookes, P.C. and Jenkinson, D.S. (1991) Field incorporation of straw and its effects on soil microbial biomass and soil inorganic N. Soil Biology and Biochemistry, 23, 171-176.

[43] Singh, J.S. and Singh, V.K. (1992) Phenology of seasonally dry tropical forest. Current Science, 63, 684-688.

[44] Moore, J.M., Klose, S. and Tabatabai, M.A. (2000) Soil microbial biomass carbon and nitrogen as affected by cropping systems. Biology and Fertility of Soils, 31 , 200-210. doi:10.1007/s003740050646

[45] Campbell, C.A., Biederbeck, V.O., Zentner, R.P. and Lafond, G.P. (1991) Effect of crop rotations and cultural practices on soil organic matter, microbial biomass and respiration in a thin black Chernozem. Canadian Journal of Soil Science, 71, 363-376.

[46] Joergensen, R.G. (1995) Die quantitative bestimmung der mikrobiellen 340 biomasse in boden mit der chlor fom-fumigations-extraktions-methode. Gottinger Bodenkundliche Berichte, Justus von Liebig, Gottingen, 104, 1-229.

[47] Wheatley, R., Ritz, K. and Griffiths, B. (1990) Microbial biomass and mineral $\mathrm{N}$ transformations in soil planted with barley, ryegrass, pea, or turnip. Plant and Soil, 17, 157-167. doi:10.1007/BF00014422

[48] Sparling, G.P. (1992) Ratio of microbial biomass carbon to soil organic carbon as a sensitive indicator of changes in soil organic matter. Australian Journal of Soil Research, 30, 195-207.

[49] McCarthy, G.W., Meisinger, J.J. and Jenniskens, F.M.M. (1995) Relationships between total-N, biomass-N and active- $\mathrm{N}$ in soil under different tillage and $\mathrm{N}$ fertilizer treatments. Soil Biology and Biochemistry, 27, 12451250. doi:10.1016/0038-0717(95)00060-R

[50] Singh, S. and Singh, J.S. (1995) Microbial biomass associated with water-stable aggregates in forest, savanna and cropland soils of a seasonally dry tropical region, India. Soil Biology and Biochemistry, 27, 1027-1023.

[51] Franzluebbers, A.J., Hons, F.M. and Zuberer, D.A. (1995) Soil organic carbon, microbial biomass, and mineralizable carbon and nitrogen in sorghum. Soil Science Society of America Journal, 56, 460-466. doi:10.2136/sssaj 1995.03615995005900020027x

[52] Witter, E., Marttensson, A.M. and Garcia, F.V. (1993) Size of the soil microbial biomass in a long-term field experiment as affected by different $\mathrm{N}$-fertilizers and organic manures. Soil Biology and Biochemistry, 25, 659669. doi:10.1016/0038-0717(93)90105-K 